Article

\title{
Carrier-Free Microspheres of an Anti-Cancer Drug Synthesized via a Sodium Catalyst for Controlled-Release Drug Delivery
}

\author{
Yong Xie ${ }^{1,2}$, Xinxin $\mathrm{Ma}^{3}$, Xujie Liu ${ }^{1, *}$, Qingming Long ${ }^{1}$, Yu Wang ${ }^{2}$, Youwei Yao ${ }^{1}$ \\ and Qiang Cai ${ }^{1,2, *}$ \\ 1 Graduate School at Shenzhen, Tsinghua University, Shenzhen 518055, China; \\ jy15@mails.tsinghua.edu.cn (Y.X.); 13303275396@163.com (Q.L.); yaoyw@sz.tsinghua.edu.cn (Y.Y.) \\ 2 State Key Laboratory of New Ceramics and Fine Processing, School of Materials Science and Engineering, \\ Tsinghua University, Beijing 100084, China; zpheadwang@163.com \\ 3 Southern China Branch, Sinopec Commercial Holding Company Limited, Guangzhou 510630, China; \\ 15201106417@163.com \\ * Correspondence: liu.xujie@sz.tsinghua.edu.cn (X.L.); caiqiang@tsinghua.edu.cn (Q.C.)
}

Received: 30 December 2017; Accepted: 6 February 2018; Published: 11 February 2018

\begin{abstract}
There are several challenges involved in the development of effective anti-cancer drugs, including accurate drug delivery without toxic side effects. Possible systemic toxicity and the rapid biodegradation of drug carriers are potential risks in the use of carriers for drug-delivery formulations. Therefore, the carrier-free drug delivery of an anti-cancer drug is desirable. Herein, 4-amino-2-benzyl-6-methylpyrimidine (ABMP) was synthesized via a new method using a sodium catalyst, and proved to be effective in inducing breast cancer cell (MDA-MB-231) apoptosis. Moreover, the transparent amorphous state solid of ABMP was demonstrated to have a slow-release property in phosphate buffer solution (PBS). Microspheres of ABMP were prepared with diameters in the range of 5-15 $\mu \mathrm{m}$. The slow-release property of the ABMP microspheres indicated their potential use for controlled-release drug delivery. We believe that microspheres of ABMP have potential as a new kind of carrier-free anti-cancer drug delivery system.
\end{abstract}

Keywords: carrier-free; 4-amino-2-benzyl-6-methylpyrimidine; biomaterial; drug delivery

\section{Introduction}

Breast cancer has become one of the most prevalent diseases, and is a leading cause of death worldwide [1-5]. Currently, considerable research is being carried out toward the development of anti-cancer drugs [6-8]. Some anti-cancer drugs, including paclitaxel and doxorubicin, have proved to be powerful in inducing apoptosis [9-12]. However, there are still many difficulties that hinder the development of chemotherapies using anti-cancer drugs. First, most anti-cancer drugs are extracted from existing organisms, and the artificial synthesis is often difficult $[13,14]$. In addition, the development of controlled-release formulations of anti-cancer drugs presents several challenges, including the low water solubility of many anti-cancer drugs, and the development of drug carriers without systemic toxicity and rapid biodegradation. Considering the problems mentioned above, a new drug delivery formulation is desirable.

It is well known that the controlled release of anti-cancer drugs plays an important role in cancer therapy. In response to problems that have occurred with the controlled release of anti-cancer drugs, considerable research has been performed, and some formulations have proved to be effective in model systems [15-17]. Drug carriers that have been designed and modified for use with anti-cancer drugs include mesoporous/microporous particles, vesicles, multifunctional dendritic polymers, micelles, 
and nanocapsules, and some of these formulations can also provide targeted release [18-23]. However, despite the merits of these drug carriers, many problems remain. The drug-loading capacity is often low, because the carriers are usually the major component, with a weight far greater than the drugs (thus, loading is generally less than $10 \%$ ) [24]. Other problems include the possible systemic toxicity and biodegradation of the carriers [25]. The drug carriers are designed to deliver a drug to a diseased region with the expectation that the carriers are inert and nontoxic. However, the systemic toxicity and subsequent degradation of carriers causes potential problems, including imposing an extra burden on the patients, and the mechanisms by which this occurs are still unclear. As a result, efforts have been made toward developing a carrier-free drug delivery system. In general, some kind of polymer and functionalized organic matter are introduced to prepare a carrier-free drug delivery system [26,27]. However, it is not known whether these introduced materials will bring new risks. There are some other methods for the preparation of carrier-free drug delivery systems, including the micronization or nanonization of solid anti-cancer drugs $[28,29]$, but the crystallization of the drug particles is a problem with this method, which limits its application [30].

Therefore, the synthesis of anti-cancer drugs that possess certain physicochemical properties is desirable for carrier-free drug delivery [31]. An anti-cancer drug that has the property of consolidation forming after quenching is an ideal material for designing carrier-free drug delivery formulations. Amino pyrimidine is a common core structure in anti-cancer drugs, and a series of amino pyrimidines have been studied and shown to be potential anti-cancer drugs [32-34], including 4-amino-2-benzyl-6-methylpyrimidine [35]. The traditional route for amino pyrimidine synthesis using guanidine and imine involves complicated procedures and high costs. The oligomerization of nitriles catalyzed by a base and an organic salt has been reported for the synthesis of the amino pyrimidine structure [36-38]. Sodium methoxide, $\operatorname{IrH}(\mathrm{CO})\left(\mathrm{PPh}_{3}\right)_{3}$, and sodium hydride have been employed as catalysts in this synthesis [39-43]. Considering the potential application of ABMP as an anti-cancer drug, a clean, simple, low-cost, environment-friendly, and effective method is desired for the synthesis of ABMP.

The establishment of an anti-cancer drug delivery model containing a carrier-free drug is highly desirable. In order to achieve carrier-free anti-cancer drug microspheres for a potential drug delivery system, a new strategy is proposed in this work. First, a new method for the synthesis of 4-amino-2-benzyl-6-methylpyrimidine (logogram: ABMP) is demonstrated. Meanwhile, the ABMP was proved to be effective in inducing human breast cancer cell (MDA-MB-231) apoptosis. This was followed by the preparation of microspheres of ABMP in a high-temperature and high-pressure system. Release tests of the transparent amorphous state solid cube and the microspheres of ABMP were also performed.

\section{Materials and Methods}

\subsection{Preparation of $A B M P$}

The experiment was carried out in an anaerobic glove box to provide water-free and oxygen-free conditions. Benzyl cyanide $(500 \mathrm{~mL})$ was put into a $1000-\mathrm{mL}$ balloon flask, and then heated to $80{ }^{\circ} \mathrm{C}$ in an oil bath. Afterwards, small pieces of sodium were added into the benzyl cyanide, piece by piece, with continuous stirring. After $12 \mathrm{~h}$, the reaction solution turned into a brown solid, then recrystallization was employed to purify the product to give ABMP as a light pink solid in approximately $90 \%$ yield.

\subsection{Characterization}

The solubility of the synthesized 4-amino-2-benzyl-6-methylpyrimidine in various solvents, including ethanol (EtOH), water $\left(\mathrm{H}_{2} \mathrm{O}\right)$, dimethyl sulfoxide (DMSO), and dimethylformamide (DMF), was investigated at a concentration of $5 \%(w / v)$. The Fourier transform infrared (FT-IR) spectrum of the synthesized amino pyrimidine was measured in the range of $4000-400 \mathrm{~cm}^{-1}$ on a FT-IR spectrometer 
(6700FTIR, Thermo Fisher Scientific, Waltham, MA, USA). ${ }^{1} \mathrm{H}$ and ${ }^{13} \mathrm{C}$ nuclear magnetic resonance $\left({ }^{1} \mathrm{H}-\mathrm{NMR}\right.$ and $\left.{ }^{13} \mathrm{C}-\mathrm{NMR}\right)$ spectra were obtained in DMSO- $d_{6}$ using a $600-\mathrm{MHz}$ NMR spectrometer (JNM-ECA600, JEOL, Akishima, Japan). Single crystal X-ray diffraction (SXRD) was executed in a single-crystal diffractometer (RIGAKU, R-Axis-Spider, Tokyo, Japan). The liquid chromatograph-mass spectra (LC-MS) of the synthesized amino pyrimidine was analyzed in a liquid chromatography-mass spectrometer (LTQ, Thermo Fisher Scientific, Waltham, MA, USA). The three-dimensional (3D) photoluminescence spectra of the synthesized amino pyrimidine were obtained using a fluorescence spectrometer (FLSP920, Edinburgh Instruments Ltd., Livingston, U.K.) with the concentration of samples set to $1 \%(w / v)$. The thermogravimetric-differential scanning calorimetry (TG-DSC) analysis was acquired from a simultaneous thermal analyzer (STA449F3, NETZSCH-Gerätebau GmbH, Selb, Germany).

\subsection{Cell Culture}

The human mammary carcinoma cell line (MDA-MB-231), the immortalized cell line of mouse fibroblast cells (L929), and the autologous bone marrow stem cell (BMSC) were selected as the experimental cell line to evaluate the effect of the synthesized 4-amino-2-benzyl-6-methylpyrimidine in inducing cancer cell apoptosis. The MDA-MB-231 cells were cultivated in L-15 (Invitrogen, Carlsbad, CA, USA) medium with 15\% fetal bovine serum (FBS; Invitrogen, USA), $100 \mu \mathrm{g} / \mathrm{mL}$ streptomycin, and $100 \mu \mathrm{g} / \mathrm{mL}$ penicillin under standard culture conditions $\left(5 \% \mathrm{CO}_{2}, 37^{\circ} \mathrm{C}\right)$. The cells (purchased from the Chinese Academy of Medical Sciences, Beijing, China) were expanded, and the medium was replaced with fresh medium every two days. Different concentrations, i.e., 0, 10, 25, 50, $75,100,125$, and $150 \mu \mathrm{g} / \mathrm{mL}$, of synthesized 4-amino-2-benzyl-6-methylpyrimidine were used to treat the cells.

\subsection{CCK-8 Assays}

The CCK-8 assay was used to observe the number of living cells. A 48-well plate was used to seed the cells at a density of 15,000 cells per well. After seeding for 24 and $48 \mathrm{~h}$ within in vitro assays, the CCK-8 assay was performed. Briefly, CCK-8 (Dojindo, Kyushu, Japan) was added to each well with a $10 \mathrm{vol} \%$ of the medium. The absorbance (OD) of the solution, after incubation for $2 \mathrm{~h}$ at $37^{\circ} \mathrm{C}$, was measured by a microplate reader at $450 \mathrm{~nm}$. The experiments were carried out in quadruplicate.

\subsection{Cell Cycle Analysis}

MDA-MB-231 cells were plated at a density of $1 \times 10^{6}$ cells/well on six-well plates. After treatment with ABMP, both detached and attached cells were collected into flow cytometry tubes, and centrifuged at $1000 \mathrm{rpm}$ for $5 \mathrm{~min}$ to obtain a cell pellet. The cells were suspended in a solution of phosphate-buffered saline (PBS) / ethylene diamine tetraacetic acid (EDTA), and an equal volume of ethanol was added to the cells, which were then incubated for $30 \mathrm{~min}$ at room temperature. Cells were collected by centrifugation. For cell cycle analysis, the ethanol-fixed cells were stained with propidium iodide (PI) in the presence of RNase A, and then analyzed by a fluorescence-activated cell sorter (FACS). In each analysis, 30,000 events were recorded.

\subsection{Apoptosis Assay}

For analyzing apoptosis, fluorescein isothiocyanate (FITC)-conjugated annexin V binding and PI staining were performed using a kit from Multi Sciences. MDA-MB-231 cells were plated at a density of $1 \times 10^{6}$ cells/well on six-well plates, and cell apoptosis was induced by ABMP treatment for $24 \mathrm{~h}$. Both detached and attached cells were collected for FITC-conjugated annexin V and PI staining. Early and late apoptotic cell populations were visualized by constructing a dot plot with the aid of FACS. The FL1 channel was used to detect annexin V-FITC staining, and the FL2 channel was used for PI staining. 


\subsection{Exploration of Amorphous State Solidification}

ABMP was formed as a transparent amorphous state solid via a quenching process. Synthesized ABMP (1 g) was put into a 20-mL glass bottle and heated to $120{ }^{\circ} \mathrm{C}$ in an oil bath for $10 \mathrm{~min}$ until a liquid phase was obtained. Then, the liquid was poured into a glass cube mold, which was placed in a cold environment. After a few minutes, a transparent amorphous state solid was formed. Repeated stretch and compression operations were executed, and soft stripes were recorded by a camera.

\subsection{Slow-Release of Ass-ABMP}

The method for drug release in a PBS solution, as reported previously, was applied to explore the potential for the carrier-free release of the amorphous state solid of ABMP. A standard curve was acquired on a UV-VIS spectrophotometer (Agilent Technologies Inc., Santa Clara, CA, USA) before the release test. Then, a cube of amorphous state solid ABMP was put into $50 \mathrm{~mL}$ of PBS solution with stirring. Dissolution medium $(2 \mathrm{~mL})$ was replaced by fresh PBS at predetermined time intervals for determination of the drug concentration.

\subsection{Preparation of Spheroidal Particles}

Spherical particles were acquired by the following procedure. Briefly, a homogeneous mixed solution containing $10 \mathrm{~mL}$ of deionized water and $1.5 \mathrm{~g}$ of Tween-40 was prepared and transferred to a $30-\mathrm{mL}$ Teflon vessel. Then, $0.2 \mathrm{~g}$ of synthesized 4-amino-2-benzyl-6-methylpyrimidine (ABMP) was added. The mixture was heated to $150{ }^{\circ} \mathrm{C}$ in an oven, and then vigorous shaking was adopted, before a cool environment was provided for quick cooling. Then, $200 \mu \mathrm{L}$ of product was placed on a piece of microslide, and the morphology was observed under an optical microscope.

\subsection{Carrier-Free Release of Spheroidal Particles}

A solution of ABMP microspheres $(3 \mathrm{~mL})$ was put into $50 \mathrm{~mL}$ of fresh phosphate-buffered saline (PBS) with stirring at $37^{\circ} \mathrm{C}$. A $0.2-\mathrm{mL}$ aliquot of solution was replaced by fresh PBS after 10, 20, and $40 \mathrm{~h}$. The morphology of the microspheres was observed by an optical microscope.

\subsection{Statistical Analysis}

The results were expressed as mean \pm standard deviation (SD). The statistical significances of differences in means were determined by the two-tailed Student $t$-test, or one-way or two-way analysis of variance (ANOVA), followed by post hoc comparisons with the least significant difference (LSD) method using SPSS 19.0 software (19th Edition, International Business Machines Corporation, Armonk, NY, USA). A value of $p<0.05$ was considered as statistically significant.

\section{Results and Discussion}

\subsection{Oligomerization of Acetonitrile}

The product was identified by different characterization methods, including ${ }^{1} \mathrm{H}$ and ${ }^{13} \mathrm{C}$ NMR, FT-IR, LC-MS and SXRD. The lattice constants of the ABMP cell are listed in Table 1. The results indicated that the ABMP cell belongs to the triclinic crystal system. The FT-IR and LC-MS spectra of the obtained product are given in Figure $1 b, c$, respectively. As shown in Figure $1 b$, the IR bands at approximately 3475 and $3296 \mathrm{~cm}^{-1}$ are dominated by the $\mathrm{N}-\mathrm{H}$ stretch vibration contribution, the 2903 and $1480 \mathrm{~cm}^{-1}$ bands indicate the existence of $\mathrm{CH}_{2}$, and the bands at 3030 and $1600-1500 \mathrm{~cm}^{-1}$ are attributed to the vibrations of aromatic nuclei. The LC-MS spectrum not only verifies the molecular weight, it also gives an indication of the purity of the product. ${ }^{1} \mathrm{H}$ NMR $\left(600 \mathrm{MHz}, \mathrm{DMSO}-d_{6}, \delta / \mathrm{ppm}\right)$ : 7.51-7.04 (m, 15H, br), $6.92\left(\mathrm{~d}, 2 \mathrm{H}, \mathrm{NH}_{2}\right), 3.88\left(\mathrm{~s}, 4 \mathrm{H}, \mathrm{CH}_{2}\right)$ (Figure 1d). The melting point of ABMP is $110{ }^{\circ} \mathrm{C}$, and the boiling point is $408^{\circ} \mathrm{C}$, which was confirmed by TG-DSC analysis, as shown in Figure 2. 


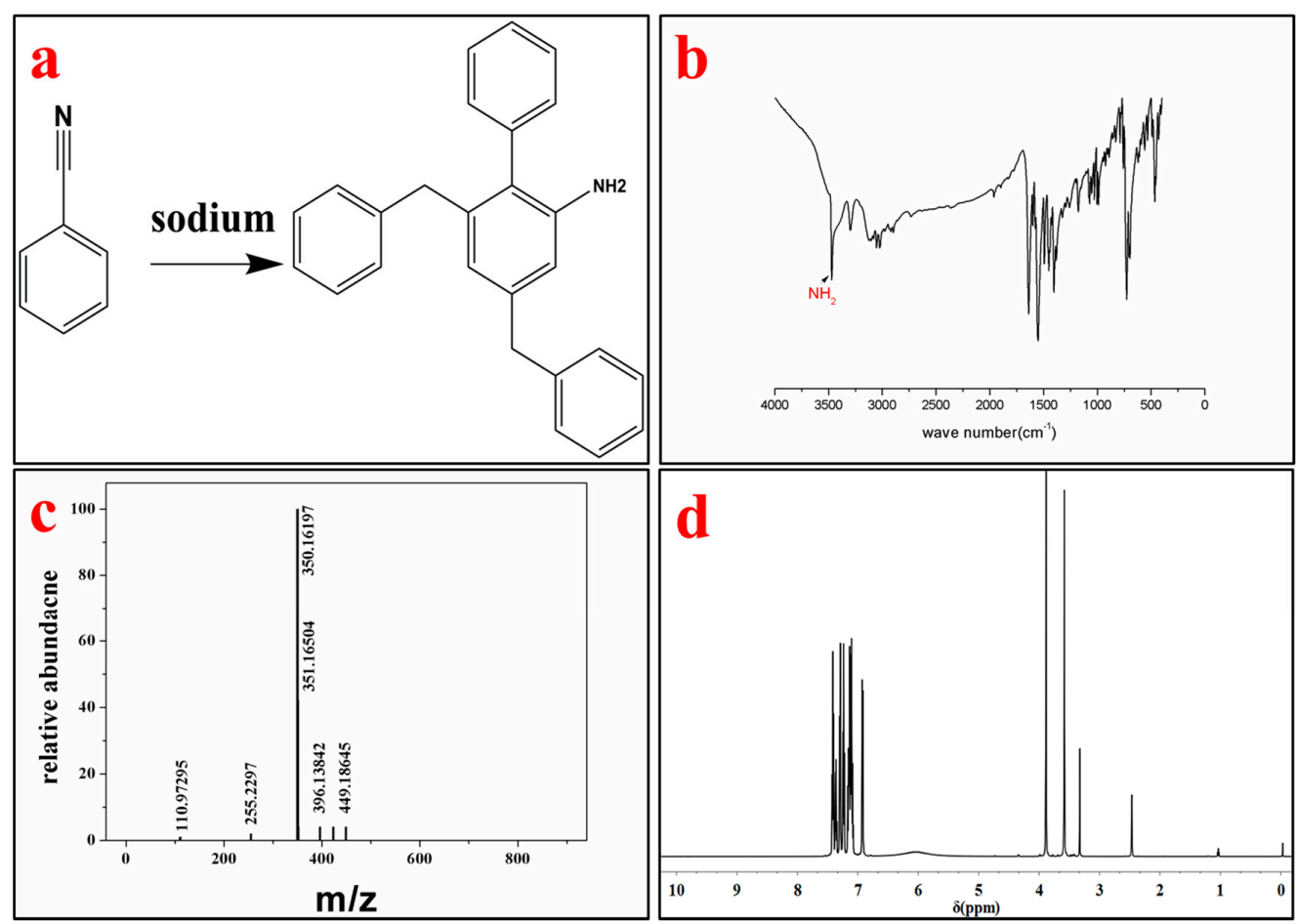

Figure 1. Synthesis and characterization of 4-Amino-2-benzyl-6-methylpyrimidine (ABMP). (a) Chemical structure of ABMP synthesized from benzyl cyanide using sodium as a catalyst; (b) Fourier transform infrared (FT-IR) spectrum of ABMP; (c) mass spectrum of ABMP; and (d) ${ }^{1} \mathrm{H}$ NMR spectrum of ABMP.

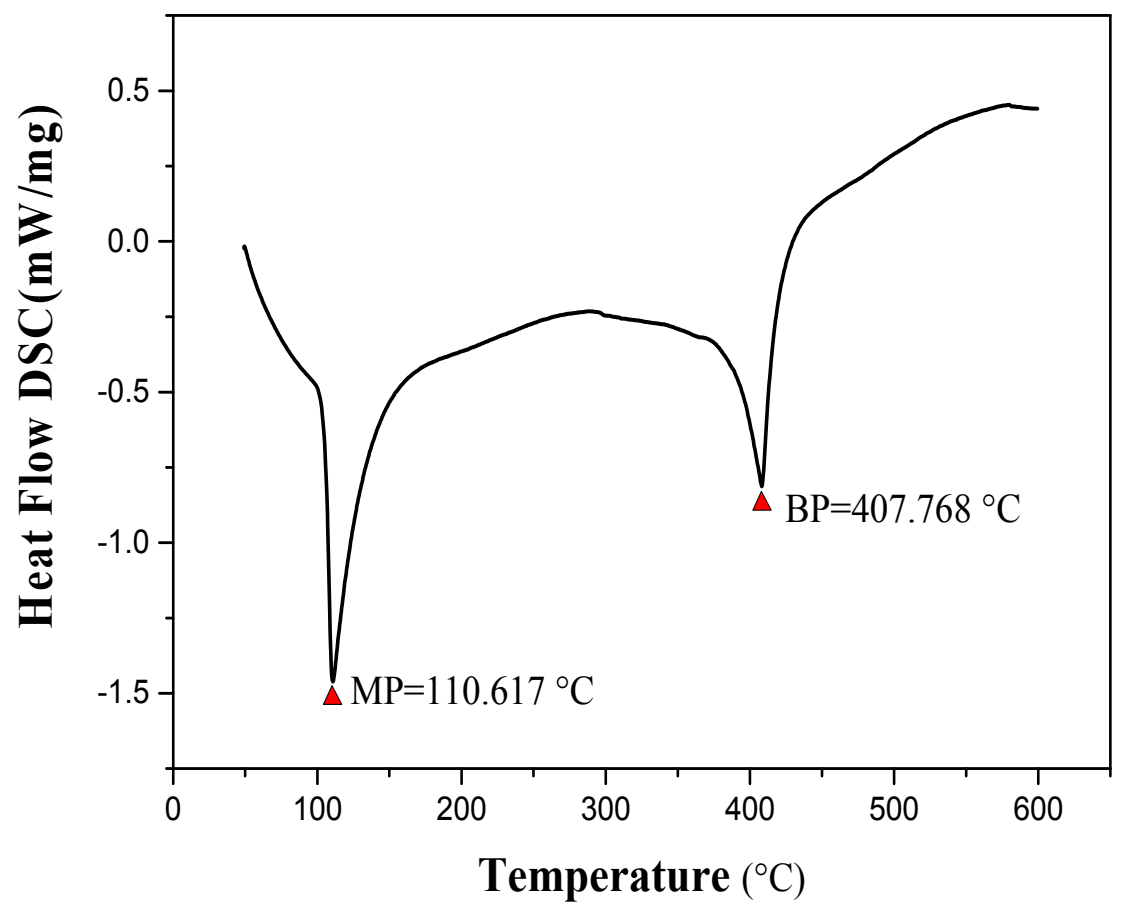

Figure 2. Differential thermal analysis of ABMP; the melting point is $110.617^{\circ} \mathrm{C}$, and the boiling point is $407.768^{\circ} \mathrm{C}$. 
Table 1. Lattice constants of the ABMP cell measured by single crystal X-ray diffraction (SXRD).

\begin{tabular}{ccccccc}
\hline $\mathbf{a}$ & $\mathbf{b}$ & $\mathbf{c}$ & $\boldsymbol{\alpha}$ & $\boldsymbol{\beta}$ & $\boldsymbol{\gamma}$ & Crystal System \\
\hline 15.1476 & 17.3671 & 23.1182 & 75.5340 & 87.8610 & 81.4140 & Triclinic \\
\hline
\end{tabular}

It is difficult to polymerize or oligomerize the carbon-nitrogen triple bonds in acetonitrile unless severe conditions are imposed. In our previous study [44], an oligomer of acetonitrile with polymerization degree $n=17$ was synthesized via an electrochemical method. In addition, a cyclotrime of acetonitrile was acquired using sodium as a catalyst under ambient conditions. The cyclotrime of acetonitrile had the ability to induce osteogenesis [45]. The $\alpha$-proton found in nitriles makes it possible for the $\alpha$-carbon to be changed into a carbanion, especially when sodium is employed. The super catalyst ability of the carbanion has the essential effect in the formation of amino pyrimidine. As is mentioned above, the one-pot method for amino pyrimidine synthesis using sodium as a catalyst has been proved to be versatile for the synthesis of small nitriles, such as acetonitrile and benzyl cyanide. There are other sites exposed, which can be used to graft various groups aimed at targeted therapy.

\subsection{Fluorescent Properties}

Encouraged by the integration of diagnostics and therapeutics, the fluorescent properties of drug candidates have become of interest in drug design and synthesis. The 3D photoluminescence spectra (Figure 3) of ABMP was acquired on a fluorescence spectrometer with the concentration of the sample set to $1 \%(w / v)$. The maximum fluorescent intensity occurs at $465 \mathrm{~nm} / 525 \mathrm{~nm}$ (excitation/emission). The conjugated $\pi-\pi$ structure provides a theoretical foundation for the fluorescent properties. In addition, the solubility of ABMP was measured at the same time, and the results indicated that it is slightly soluble in deionized water, and very soluble in ethanol (EtOH), dimethyl sulfoxide (DMSO), dimethylformamide (DMF), and tetrahydrofuran.
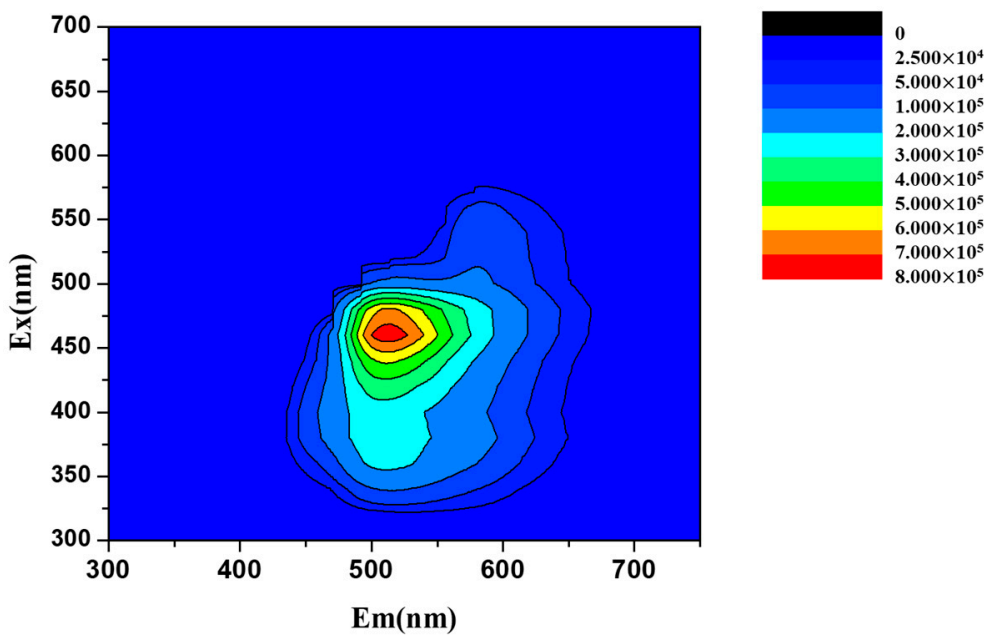

Figure 3. Three-dimensional (3D) photoluminescence spectra of ABMP in ethanol with the concentration of the sample set to $1 \%(w / v)$.

\subsection{Ability to Induce Cancer Cell Apoptosis}

\subsubsection{ABMP Inhibited MDA-MB-231 Breast Cancer Cell Proliferation}

The inhibitory effects of ABMP on human breast cancer cells was assessed using MDA-MB-231 cells. MDA-MB-231 cells are a type of human breast cancer cell that are widely used to evaluate the efficacy of anti-cancer drugs [46]. Different concentrations, i.e., 0, 10, 25, 50, 75, 100, 125, and $150 \mu \mathrm{g} / \mathrm{mL}$ of ABMP were used to treat MDA-MB-231 cells. The relative cell numbers determined by the OD 
value using CCK-8 at days 1 and 2 are shown in Figure 4. The results suggested that ABMP inhibited MDA-MB-231 breast cancer cell proliferation in a dose and time-dependent manner. After 24-h treatment with $25 \mu \mathrm{g} / \mathrm{mL}$ ABMP, the percentage of dead cells was $\sim 50 \%$, and by $48 \mathrm{~h}$, this had increased to $79 \%$. At a dosage of $50 \mu \mathrm{g} / \mathrm{mL}$ of ABMP, the percentage of dead cells increased to $69 \%$ after $24 \mathrm{~h}$, and $99 \%$ at $48 \mathrm{~h}$. The $\mathrm{IC}_{50}$ value of MDA-MB-231 for ABMP was $25 \mu \mathrm{g} / \mathrm{mL}(71 \mathrm{nM})$. Meanwhile, the contrastive experiment was executed, and the results were shown in Figure 5. It turned out that the normal cell viability of L929 and BMSC was slightly influenced (the number of cell deaths is less than $80 \%$ ) after treatment with ABMP at concentrations between $10-75 \mu \mathrm{g} / \mathrm{mL}$, suggesting a low cytotoxicity in this concentration range. Furthermore, the MDA-MB-231 cell numbers and viability were evaluated using calcein-AM $\left(3^{\prime}, 6^{\prime}\right.$-Di( $O$-acetyl)-4', $5^{\prime}$-bis[ $N, N$-bis(carboxymethyl)aminomethyl]fluorescein, tetraacetoxymethyl ester)/PI (phosphatidylinositol) staining after 48-h seeding, and the results (Figure 6) were collected after 48-h seeding. In Figure 6, the cells with green are alive, while dead cells are shown in red. The cell numbers and viability were observed to gradually decrease with an increase in ABMP concentration. When $150 \mu \mathrm{g} / \mathrm{mL}$ of ABMP was employed for $48 \mathrm{~h}$, MDA-MB-231 cells were almost completely annihilated, which demonstrated a good performance of ABMP in inhibiting cancer cell proliferation.

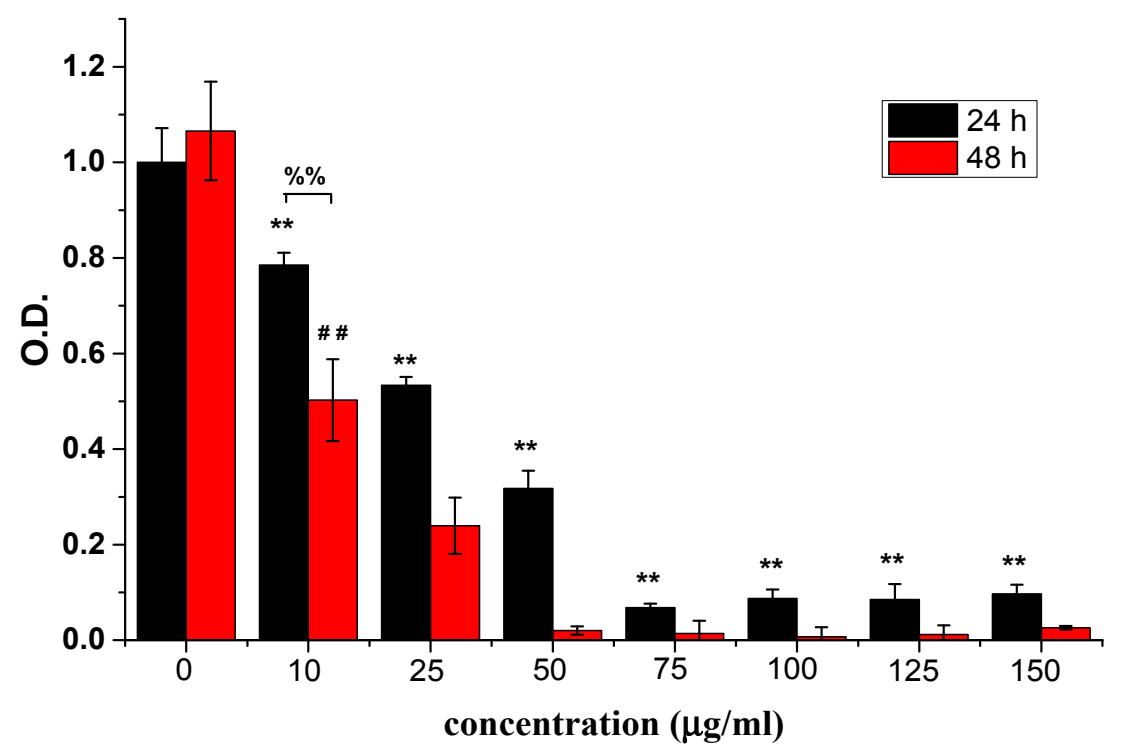

Figure 4. Relative cell numbers determined by the absorbance (OD) value using CCK- 8 at 24 and $48 \mathrm{~h}$. Breast cancer cells (MDA-MB-231) were treated with ABMP at different concentrations, i.e., 0, 10, 25, 50, $75,100,125$, and $150 \mu \mathrm{g} / \mathrm{mL}$. The experiments were carried out in quadruplicate. Double asterisks $\left(^{* *}\right)$ and double pounds (\#\#) refer to statistical significance $p<0.01$ compared with control groups. Double percent $(\% \%)$ refers to a statistical significance of $p<0.01$ between the OD values after seeding for 24 and $48 \mathrm{~h}$. 


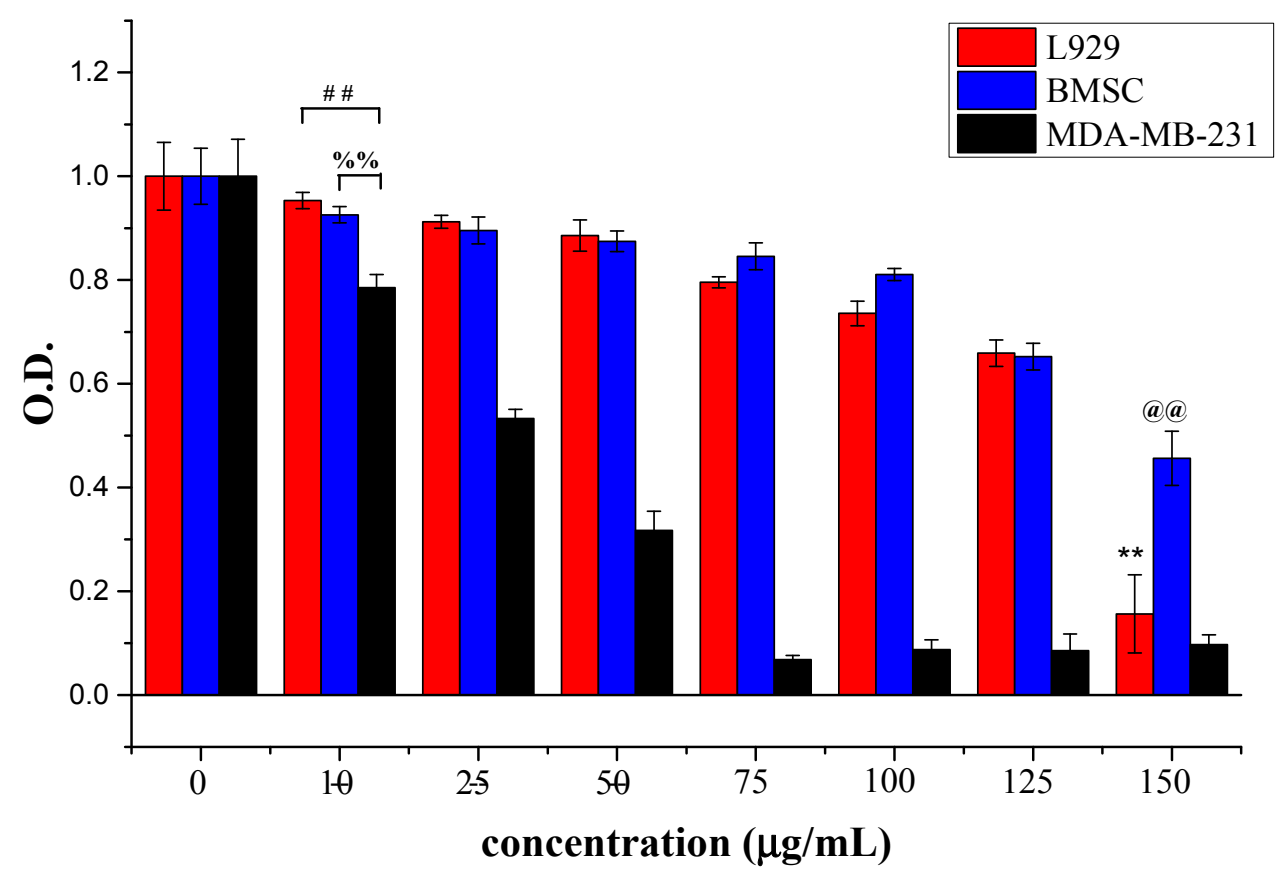

Figure 5. Relative cell numbers determined by the OD value using CCK-8 at $24 \mathrm{~h}$. L929, bone marrow stem cell (BMSC), and MDA-MB-231 cells were treated with ABMP at different concentrations, i.e., 0 , $10,25,50,75,100,125$, and $150 \mu \mathrm{g} / \mathrm{mL}$. The experiments were carried out in quadruplicate. Double asterisks $\left(^{* *}\right)$ and double at (@@) refer to statistical significance $p<0.01$ compared with control groups. Double pound (\#\#) refers to a statistical significance of $p<0.01$ between the OD values of L929 and MDA-MB-231 after seeding for $24 \mathrm{~h}$; double percent (\%\%) refers to a statistical significance of $p<0.01$ between the OD values of BMSC and MDA-MB-231 after seeding for $24 \mathrm{~h}$.

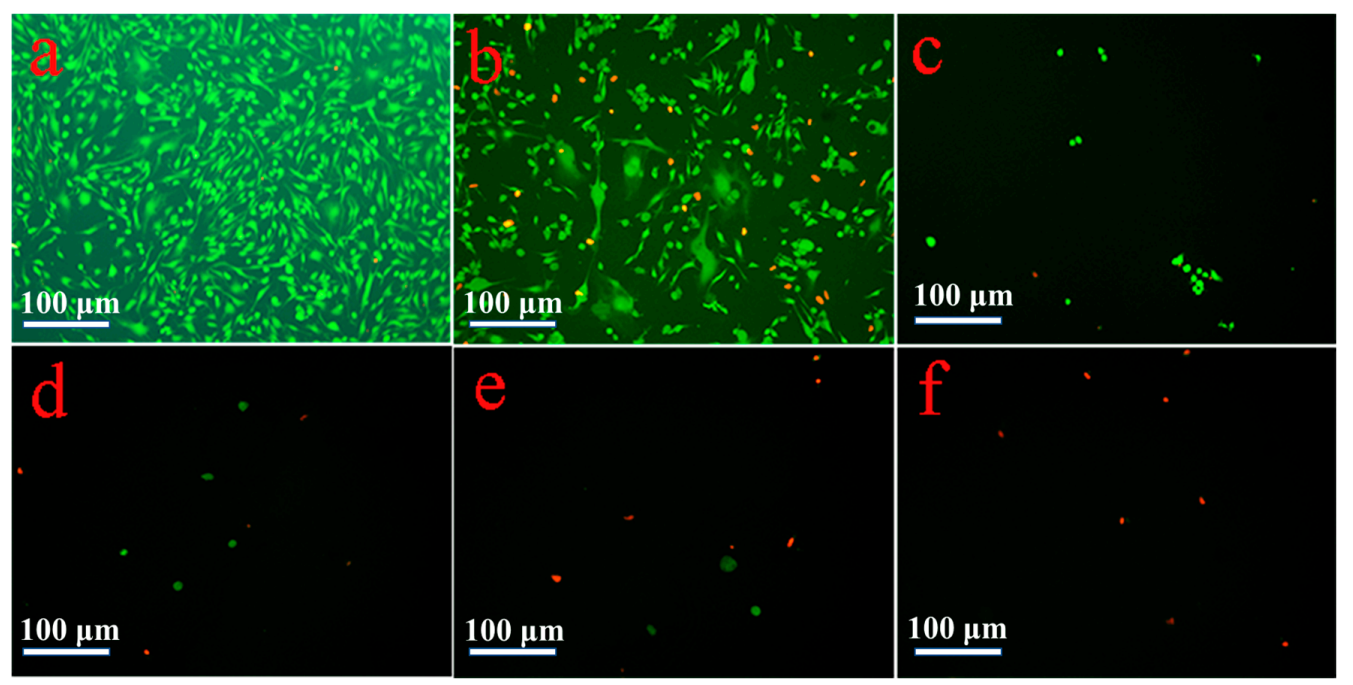

Figure 6. Cell numbers and viability evaluated using calcein-AM/ propidium iodide (PI) staining after 48-h seeding. (a) Control; (b) $25 \mu \mathrm{g} / \mathrm{mL}$; (c) $50 \mu \mathrm{g} / \mathrm{mL}$; (d) $75 \mu \mathrm{g} / \mathrm{mL}$; (e) $100 \mu \mathrm{g} / \mathrm{mL}$; and (f) $125 \mu \mathrm{g} / \mathrm{mL}$.

\subsubsection{ABMP-Induced Apoptosis of MDA-MB-321 Cancer Cells}

In order to study the mechanism of antiproliferative activity by ABMP, the cell cycle distributions of MDA-MB-231 cells affected by ABMP were analyzed in detail. Cells were treated with various concentrations of ABMP for $24 \mathrm{~h}$ and subject to FACS analysis after PI staining of the chromosomal DNA. In histograms of FACS analysis, untreated proliferative MDA-MB-231 cells showed cell cycle 
distributions of $47.12 \%$ in $\mathrm{G} 1 / \mathrm{G} 0,10.18 \%$ in $\mathrm{S}, 40.24 \%$ in $\mathrm{G} 2 / \mathrm{M}$, and $2.46 \%$ in the sub-G1/G0 phase. However, after ABMP treatment, G1/G0 and sub G1/GO populations increased in an ABMP-dose dependent manner. At $75 \mu \mathrm{g} / \mathrm{mL}$ of $\mathrm{ABMP}$, the populations reached a minimum of $4.73 \%$ for $\mathrm{S}$, and $28.72 \%$ for G2/M. In contrast, the populations increased up to $58.82 \%$ in the G1/G0 phase, and $7.73 \%$ in the sub-G1/G0 phase after treatment with $75 \mu \mathrm{g} / \mathrm{mL}$ of ABMP (Figure 7). These data indicated that ABMP has an activity to arrest MDA-MB-231 cell growth in G0/G1. The simultaneous staining of cells with annexin-V and PI dye made it possible to distinguish between early apoptotic cells (stained positive for annexin-V and negative for PI), and late apoptotic or necrotic cells (stained positive for both annexin- $\mathrm{V}$ and $\mathrm{PI}$ ); the results were shown in Figure 8. In MDA-MB-231 control culture, the number of apoptotic cells is negligible (Figure 8a). After $24 \mathrm{~h}$ of treatment with ABMP, the population in the early stages continuously increased with the amount of treated ABMP, giving a maximum value of about $80.4 \%$ at $75 \mu \mathrm{g} / \mathrm{mL}$ of ABMP (Figure $8 \mathrm{~d}$ ). On the other hand, the population of cancer cells in the late apoptotic or necrotic stage significantly increased. It reached a maximum value of approximately $14.6 \%$ at $50 \mu \mathrm{g} / \mathrm{mL}$ of ABMP, then slightly decreased from this maximum value as the concentration of $A B M P$ became higher. These results indicated that the persistent presence of ABMP at concentrations of $25-75 \mu \mathrm{g} / \mathrm{mL}$ can cause significant MDA-MB-231 cell death through the apoptotic pathways.

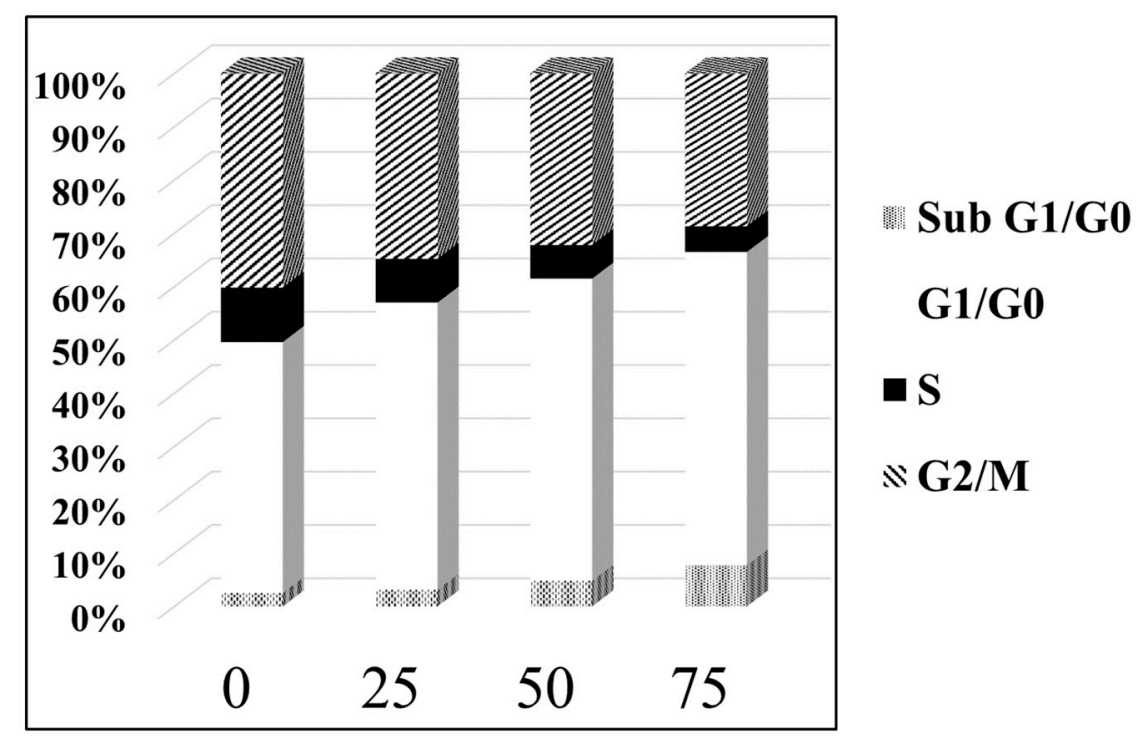

\section{Concentration $(\mu \mathrm{g} / \mathrm{mL})$}

Figure 7. ABMP arrests MDA-MB-231 cells in G0/G1. Proliferating MDA-MB-231 cells were treated with various concentrations of ABMP for $24 \mathrm{~h}$, fixed with ethanol, and stained with PI. Cell cycle distributions were analyzed by fluorescence-activated cell sorter (FACS) analysis.

Paclitaxel and doxorubicin are known to have an effect on inducing cancer cell apoptosis and have been in clinical use, but there are still many existing limitations that hinder their clinical application, including the high cost caused by the complicated procedures for preparation, poor aqueous solubility, and the need for a carrier for controlled release. Although ABMP has a high $\mathrm{IC}_{50}$ value for MDA-MB-231 cells $(71.22 \mathrm{nM})$ compared with paclitaxel (2.4 nM) [47], there are some advantages for ABMP over traditional anti-cancer drugs. First, the method for the preparation of $\mathrm{ABMP}$ has been proved to be useful for the synthesis of drugs containing pyrimidine via a bottom-up process, which provided more opportunities to construct new molecules with desired biocompatibility. Second, the ABMP system is solvent-free, simple, inexpensive, environmentally friendly, and has fluorescent properties, which gives the ABMP system advantages over traditional drugs, despite a 
reduction in the induction of cell apoptosis. The toxicity in vivo, and the mechanism by which ABMP induces cancer cell apoptosis, will be explored in future work by our group.
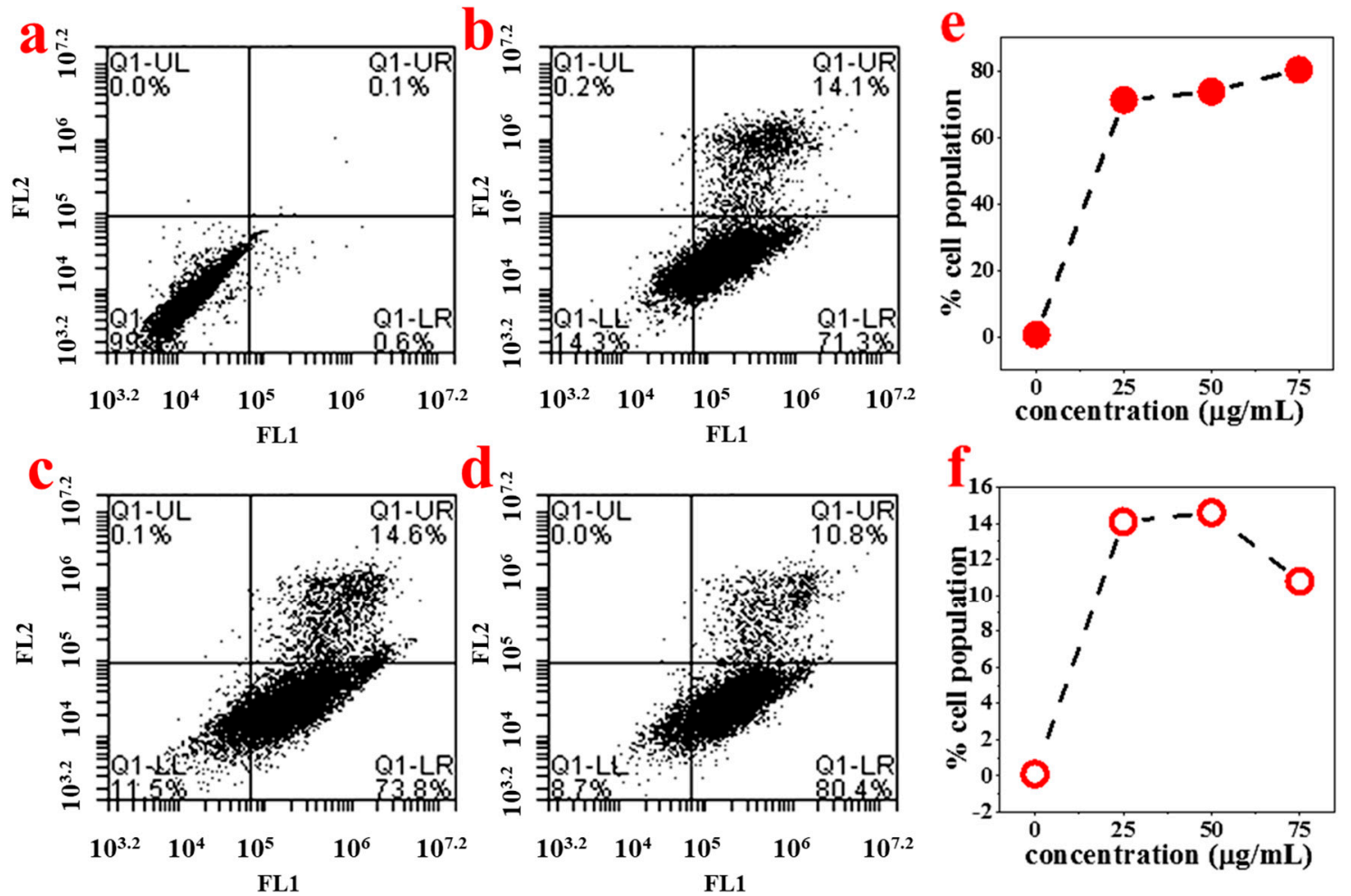

Figure 8. Histograms from FACS analysis at each ABMP concentration. The FL1 channel was used to detect annexin V-FITC staining, and the FL2 channel was for PI staining. (a) Control; (b) $25 \mu \mathrm{g} / \mathrm{mL}$; (c) $50 \mu \mathrm{g} / \mathrm{mL}$; (d) $75 \mu \mathrm{g} / \mathrm{mL}$; (e) percentage of early apoptotic cells stained with annexin-V-FITC at various concentrations of ABMP; (f) percentage of late apoptotic or necrotic cells stained with both annexin V-FITC and PI at various concentrations of ABMP.

\subsection{Potential of $A B M P$ as a Biomaterial in a Carrier-Free Release Drug Model}

A preliminary experiment was executed to explore the possibility that ABMP may form a solid state with a slow-release ability. A transparent amorphous state solid was formed when ABMP was heated to $120^{\circ} \mathrm{C}$ and rapidly cooled (Figure 9a). The rapid cooling made it difficult for the unordered molecules in the liquid to form crystals so that the mixing and enwinding of side groups occurred, and thus, an amorphous state was formed. The transparency was controlled by the condensate depression. Moreover, the transparent amorphous state solid ABMP (ass-ABMP) was transformable when an outside force was employed. Ass-ABMP could be stretched like polymer materials (Figure 9b), and the performance could be easily repeated. (Figure 9c,d). In addition, ass-ABMP had a slow dissolution ability in water and ethanol. An elaborate test was executed to explore whether ass-ABMP has the potential for slow release (Figure 10). A cube of ass-ABMP was added to $100 \mathrm{~mL}$ of PBS solution with continuous stirring. In the first few hours, the ass-ABMP showed fast-release behavior, because of the high concentration difference. When the saturation concentration occurred after $10 \mathrm{~h}$, the release speed became quite sluggish. It was observed that only $12.79 \%$ was released after $30 \mathrm{~h}$, and the release curve was in line with those for particles used for drug delivery; this provided strong evidence that ass-ABMP has the potential for slow release. The ${ }^{1} \mathrm{H}$ NMR spectra demonstrated that the solidification was a physical change only, and the structure of ABMP was not changed after dissolution in either water or PBS. 


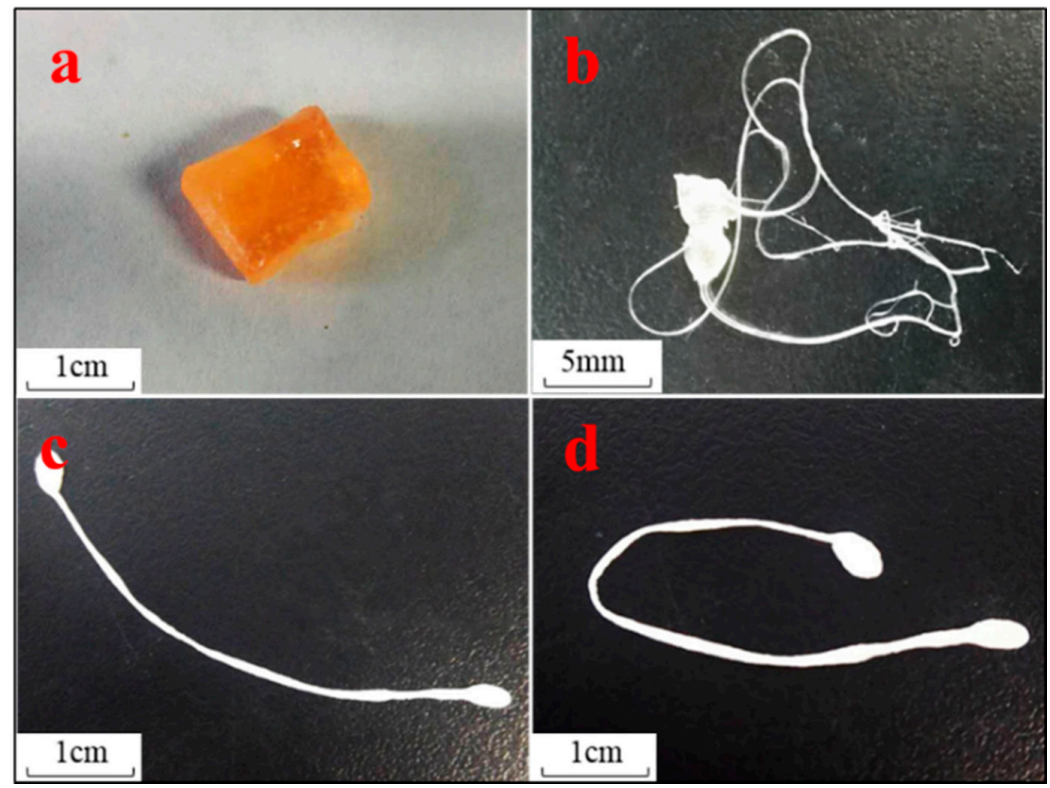

Figure 9. Transparent amorphous state solid of ABMP. (a) Appearance of amorphous state solid ABMP (ass-ABMP); (b) filiform appearance of ass-ABMP when an outside force was employed; (c,d) deformation is still possible after stretching several times.

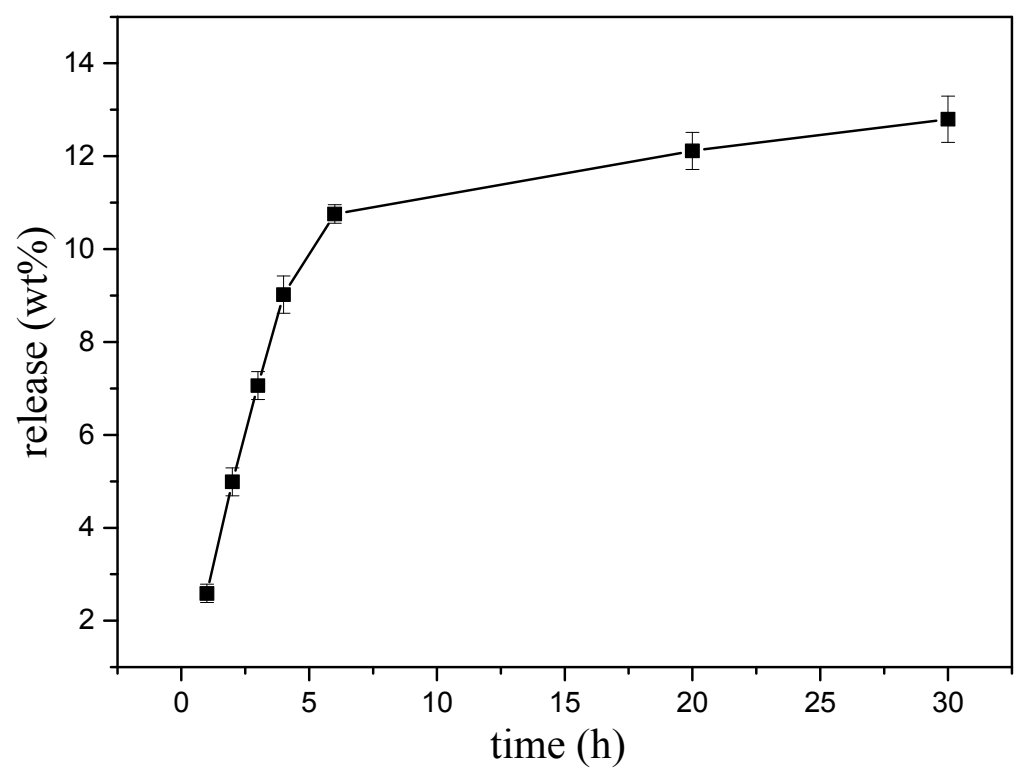

Figure 10. Slow-release curve of ass-ABMP in phosphate-buffered saline (PBS) solution. The test was executed three times under the same conditions.

\subsection{Microspheres of ABMP}

The morphology of the prepared microspheres of ABMP is shown in Figure 11. The diameter of the microspheres was in the range 5-15 $\mu \mathrm{m}$, and the microspheres were separate to each other (Figure 11a). When the preparation was heated to $150{ }^{\circ} \mathrm{C}, \mathrm{ABMP}$ became liquid, which was mixed with water. Then, when quenched with violent shaking, the tween-40 packed the ABMP into a sphere, and the liquid phase solidified from the quenching, and turned into the amorphous state. The detailed morphology is displayed in Figure 11b, in which the size and the solidification state of the ABMP microspheres can be seen. 


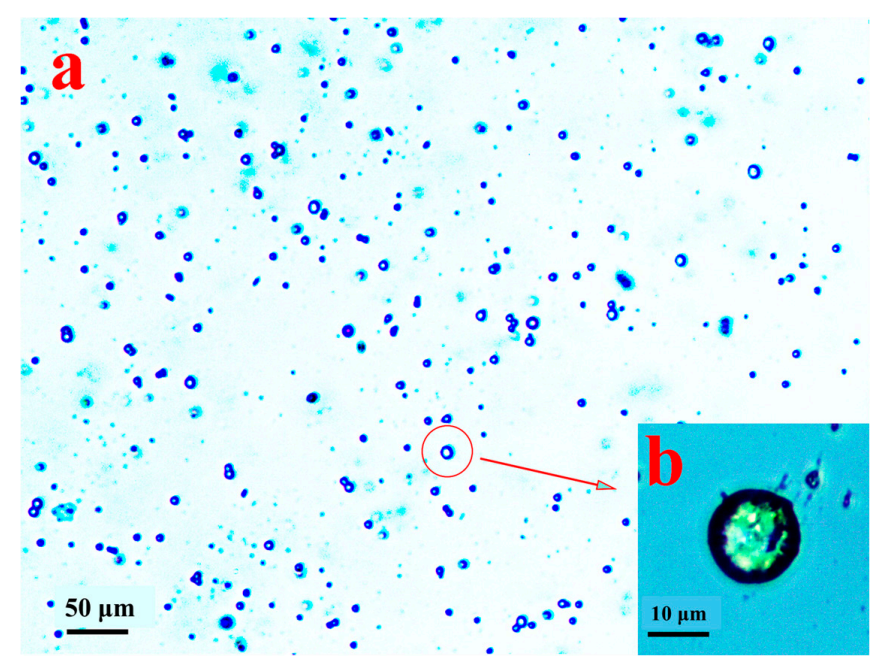

Figure 11. Morphology of microspheres of ABMP under an optical microscope: (a) overall distribution in a low-power image (100 times); and (b) the detailed morphology in a high-power image (400 times).

Using PBS as a simulative fluid condition at $37^{\circ} \mathrm{C}$, the slow-release behavior of ABMP microspheres was assessed by observing the morphological changes of the microspheres. The microspheres were investigated at different time points, and the observed morphology is shown in Figure 12. Figure 12a shows the morphology of the control group, and Figure 12b-d show the morphology of the microsphere after 10, 20, and $40 \mathrm{~h}$, respectively. The size of the microspheres became smaller with an increase in the release time. The release proportion was assessed according to the loss in the volume of the microsphere. The results indicated that $63.7 \%, 89.2 \%$, and $97.2 \%$ of ABMP was released into the PBS after 10, 20, and $40 \mathrm{~h}$, respectively. Compared with the ass-ABMP cube, the dissolution velocity was high.

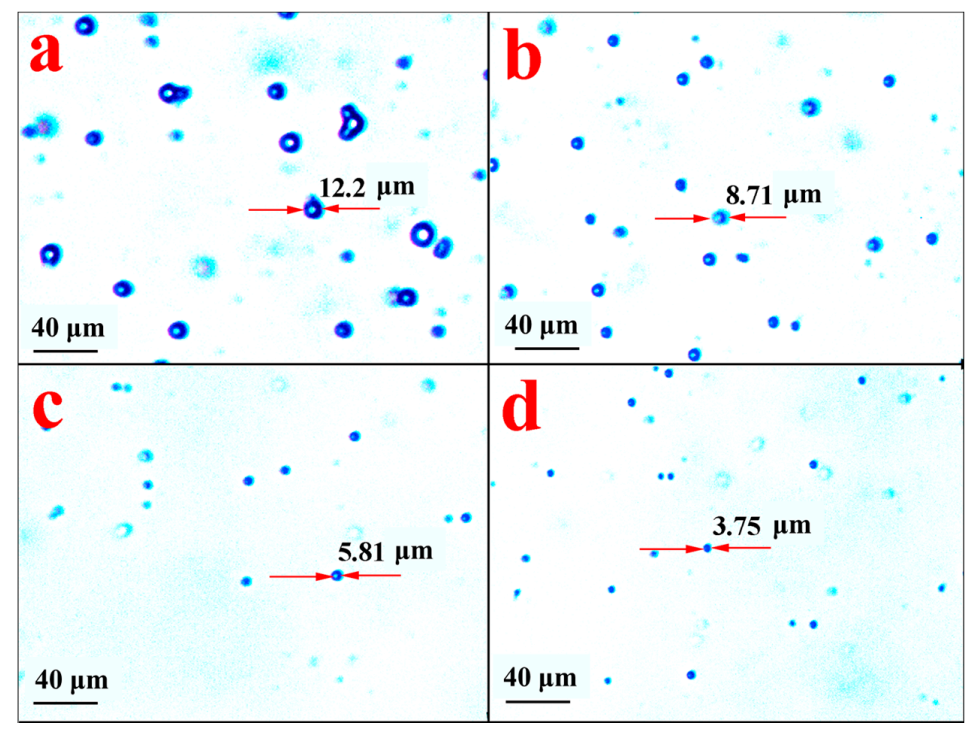

Figure 12. Morphology of ABMP microspheres under an optical microscope after release for (a) 0 h; (b) $10 \mathrm{~h}$; (c) $20 \mathrm{~h}$; and (d) $40 \mathrm{~h}$ in PBS. The diameter of a typical particle is labeled in each picture.

Microspheres that consisted of only an anti-cancer drug have been prepared and proved to be effective in the slow release of ABMP. These results provide a new research strategy for the design of carrier-free drug release formulations. Unlike other methods for preparing carrier-free drug delivery systems, such as the solvent exchange [48] or micronization/nanonization methods [49], the employed emulgator-assisted solidification method in this study resulted in naked and amorphous microspheres 
of an anti-cancer drug. In addition, efforts to decrease the size of the microspheres are underway in our group. Meanwhile, more detailed studies investigating the anti-cancer mechanism and the anti-cancer effect in vivo are also being pursued.

\section{Conclusions}

A new sodium catalytic reaction applied to benzyl cyanide cyclopolymerization to synthesize amino pyrimidine has been developed. The method is solvent-free, simple, inexpensive, and environment-friendly, which increases its potential for application in the design of medicinal molecules. The developed method using sodium as a catalyst can be also applied to the synthesis of other amino pyrimidine structures with different side chains, using different small nitrile molecules, which may also have potential in biomedical applications. Moreover, ABMP, the main product of the benzyl cyanide cyclopolymerization reaction, possesses many gratifying characteristics for a potential anti-cancer drug. In particular, it has a satisfactory $\mathrm{IC}_{50}$ value $(25 \mu \mathrm{g} / \mathrm{mL})$, combined with intrinsic fluorescent properties.

In addition, as a transparent amorphous state solid, ABMP shows carrier-free release behavior, which may be used in drug delivery systems. The ass-ABMP release test was the first attempt at using an amorphous state solid amino pyrimidine anti-cancer drug for carrier-free drug release. In addition, microspheres of ABMP were prepared by a new method. A release test indicated that the microspheres of ABMP have the potential for controlled release in a carrier-free drug delivery model.

Acknowledgments: The authors are grateful for the financial support from the National Natural Science Foundation of China (31600763) and Projects of Basic Research of Shenzhen (JCYJ20160531195524566).

Author Contributions: Yong Xie, Xujie Liu and Qiang Cai conceived and designed the experiments; Yong Xie, Yu Wang and Qingming Long performed the experiments; Yong Xie and Xujie Liu analyzed the data; Xinxin Ma and Youwei Yao contributed reagents/materials/analysis tools; Yong Xie wrote the paper.

Conflicts of Interest: The authors declare no conflict of interest.

\section{References}

1. Ferlay, J.; Soerjomataram, I.; Dikshit, R.; Eser, S.; Mathers, C. Cancer incidence and mortality worldwide: Sources, methods and major patterns in GLOBOCAN 2012. Int. J. Cancer 2015, 136, 359-386. [CrossRef] [PubMed]

2. Anderson, G.L.; Limacher, M.; Assaf, A.R.; Bassford, T.; Beresford, S. Effects of conjugated, equine estrogen in postmenopausal women with hysterectomy-The women's health initiative randomized controlled trial. J. Am. Med. Assoc. 2004, 291, 1701-1712.

3. Lim, S.S.; Vos, T.; Flaxman, A.D.; Danaei, G.; Shibuya, K. A comparative risk assessment of burden of disease and injury attributable to 67 risk factors and risk factor clusters in 21 regions, 1990-2010: A systematic analysis for the Global Burden of Disease Study 2010. Lancet 2012, 380, 2224-2260. [CrossRef]

4. Fan, L.; Strasser-Weippl, K.; Li, J.; St Louis, J.; Finkelstein, D.M. Breast cancer in China. Lancet Oncol. 2014, 15, 279-289. [CrossRef]

5. Fruman, D.A.; Rommel, C. PI3K and cancer: Lessons, challenges and opportunities. Nat. Rev. Drug Discov. 2014, 13, 140-156. [CrossRef] [PubMed]

6. Dai, J.; Mumper, R.J. Plant phenolics: Extraction, analysis and their antioxidant and anticancer properties. Molecules 2010, 15, 7313-7352. [CrossRef] [PubMed]

7. Ferrari, M. Cancer nanotechnology: Opportunities and challenges. Nat. Rev. Cancer 2005, 5, $161-171$. [CrossRef] [PubMed]

8. Wang, D.; Lippard, S.J. Cellular processing of platinum anticancer drugs. Nat. Rev. Drug. Discov. 2005, 4, 307-320. [CrossRef] [PubMed]

9. Raymond, E.; Chaney, S.G.; Taamma, A.; Cvitkovic, E. Oxaliplatin: A review of preclinical and clinical studies. Ann. Oncol. 1998, 9, 1053-1071. [CrossRef] [PubMed]

10. Di Nicolantonio, F.; Mercer, S.J.; Knight, L.A.; Gabriel, F.G. Cancer cell adaptation to chemotherapy. BMC Cancer 2005, 5, 78. [CrossRef] [PubMed]

11. Cragg, G.M. Paclitaxel (Taxol ${ }^{\circledR}$ ): A success story with valuable lessons for natural product drug discovery and development. Med. Res. Rev. 1998, 18, 315-331. [CrossRef] 
12. Speth, P.A.J.; Van, H.Q.; Haanen, C. Clinical pharmacokinetics of doxorubicin. Clin. Pharmacokinet. 1988, 15, 15-31. [CrossRef] [PubMed]

13. Rida, S.M.; El-Hawash, S.A.M.; Fahmy, H.T.Y.; Hazzaa, A.A.; El-Meligy, M.M.M. Synthesis of novel benzofuran and related benzimidazole derivatives for evaluation of in vitro anti-HIV-1, anticancer and antimicrobial activities. Arch. Pharm. Res. 2006, 29, 826-833. [CrossRef] [PubMed]

14. Matsuya, Y.; Kobayashi, Y.; Kawaguchi, T.; Hori, A.; Watanabe, Y.; Ishihara, K.; Ahmed, K.; Wei, Z.; Yu, D.; Zhao, Q.; et al. Design, synthesis, and biological evaluation of artificial macrosphelides in the search for new apoptosis-inducing agents. Chem. Eur. J. 2009, 15, 5799-5813. [CrossRef] [PubMed]

15. Mu, L.; Feng, S.S. A novel controlled release formulation for the anticancer drug paclitaxel (Taxol): PLGA nanoparticles containing vitamin E TPGS. J. Control. Release 2003, 86, 33-48. [CrossRef]

16. Zhang, L.; Xia, J.; Zhao, Q.; Liu, L.; Zhang, Z. Functional graphene oxide as a nanocarrier for controlled loading and targeted delivery of mixed anticancer drugs. Small 2010, 6, 537-544. [CrossRef] [PubMed]

17. Huiyun, W.; Dong, H.; Liu, J.; Shen, A.; Li, Y.; Shi, D. Redox-mediated dissociation of PEG-polypeptide-based micelles for on-demand release of anticancer drugs. J. Mater. Chem. B 2016, 4, 7859-7869.

18. Slowing, I.; Viveroescoto, J.; Wu, C.; Lin, V. Mesoporous silica nanoparticles as controlled release drug delivery and gene transfection carriers. Adv. Drug Deliv. Rev. 2008, 60, 1278-1288. [CrossRef] [PubMed]

19. Heleg-Shabtai, V.; Aizen, R.; Sharon, E.; Sohn, Y.S.; Trifonov, A.; Enkin, N.; Freage, L.; Nechushtai, R.; Willner, I. Gossypol-capped mitoxantrone-loaded mesoporous $\mathrm{SiO}_{2} \mathrm{NPs}$ for the cooperative controlled release of two anti-cancer drugs. ACS Appl. Mater. Interface 2016, 8, 14414-14422. [CrossRef] [PubMed]

20. Zhong, Z.; Liu, Z.; Zhang, X.; Huang, J.; Yu, X.; Li, J.; Xiong, D.; Sun, X.; Luo, Y. Effect of a controlled-release drug delivery system made of oleanolic acid formulated into multivesicular liposomes on hepatocellular carcinoma in vitro and in vivo. Int. J. Nanomed. 2016, 11, 3111-3129. [CrossRef] [PubMed]

21. Liao, W.; Sohn, Y.S.; Riutin, M.; Cecconello, A.; Parak, W.J.; Nechushtai, R.; Willner, I. The application of stimuli-responsive VEGF- and ATP-aptamer-based microcapsules for the controlled release of an anticancer drug, and the selective targeted cytotoxicity toward cancer cells. Adv. Funct. Mater. 2016, 26, 4262-4273. [CrossRef]

22. Kamaly, N.; Yameen, B.; Wu, J.; Farokhzad, O.C. Degradable controlled-release polymers and polymeric nanoparticles: Mechanisms of controlling drug release. Chem. Rev. 2016, 116, 2602-2663. [CrossRef] [PubMed]

23. Zhang, C.; Pan, D.; Li, J.; Hu, J.; Bains, A.; Guys, N.; Zhu, H.; Li, X.; Luo, K.; Gong, Q.; et al. Enzyme-responsive peptide dendrimer-gemcitabine conjugate as a controlled-release drug delivery vehicle with enhanced antitumor efficacy. Acta Biomater. 2017, 55, 153-162. [CrossRef] [PubMed]

24. Cao, Z.; Yu, Q.; Xue, H.; Cheng, G.; Jiang, S. Nanoparticles for drug delivery prepared from amphiphilic PLGA zwitterionic block copolymers with sharp contrast in polarity between two blocks. Angew. Chem. 2010, 49, 3771-3776. [CrossRef] [PubMed]

25. Poland, C.A.; Duffin, R.; Kinloch, I.; Maynard, A.; Wallace, W.A.; Seaton, A.; Stone, V.; Brown, S.; Macnee, W.; Donaldson, K. Carbon nanotubes introduced into the abdominal cavity of mice show asbestos-like pathogenicity in a pilot study. Nat. Nanotechnol. 2008, 3, 423-428. [CrossRef] [PubMed]

26. Li, W.; Yang, Y.; Wang, C.; Liu, Z.; Zhang, X.; An, F.; Diao, X.; Hao, X.; Zhang, X. Carrier-free, functionalized drug nanoparticles for targeted drug delivery. Chem. Commun. 2012, 48, 8120-8122. [CrossRef] [PubMed]

27. Zhang, R.; Xing, R.; Jiao, T.; Ma, K.; Chen, C.; Ma, G.; Yan, X. Carrier-free, chemophotodynamic dual nanodrugs via self-assembly for synergistic antitumor therapy. ACS Appl. Mater. Interfaces 2016, 8, 13262-13269. [CrossRef] [PubMed]

28. Gassmann, P.; List, M.; Schweitzer, A.; Sucker, H. Hydrosols: Alternatives for the parenteral application of poorly water soluble drugs. Eur. J. Pharm. Biopharm. 1994, 2, 64-72.

29. Muller, R.H.; Becker, R.; Kruss, B.; Peters, K. Pharmaceutical Nanosuspensions for Medicament Administration as Systems with Increased Saturation Solubility and Rate of Solution. U.S. Patent No. 5858410, 12 January 1999.

30. Muller, R.H.; Jacobs, C.; Kayser, O. Nanosuspensions as particulate drug formulations in therapy. Rationale for development and what we can expect for the future. Adv. Drug Deliv. Rev. 2001, 47, 3-19. [CrossRef]

31. Anita, P.; Khushbu, P. A review on drug nanocrystal a carrier free drug delivery. Int. J. Res. Ayurveda Pharm. 2011, 2, 448-458.

32. Selvam, T.P.; James, C.R.; Dniandev, P.V. A mini review of pyrimidine and fused pyrimidine marketed drugs. Res. Pharm. 2015, 2, 33. 
33. Appari, R.D.; Chen, X.; Chilukuri, R. Amino Pyrimidine Anticancer Compounds. U.S. Patent No. 8399433, 19 March 2013.

34. Taylor, E.C.; Liu, B. A new and efficient synthesis of pyrrolo [2,3-d] pyrimidine anticancer agents: Alimta (LY231514, MTA), homo-alimta, TNP-351, and some aryl 5-substituted pyrrolo [2,3-d] pyrimidines. J. Org. Chem. 2003, 68, 9938-9947. [CrossRef] [PubMed]

35. Eliot, M.R.; York, A.T.; Milton, B. Compounds and Methods of Use thereof for Treating Tumors. U.S. Patent No. 9695108, 4 July 2017.

36. Hauser, C.R.; Humphlett, W.J. The influence of structure on the reactions of grignard reagents with nitriles having $\alpha$-hydrogen. J. Org. Chem. 1950, 2, 359-366. [CrossRef]

37. Burns, T.P.; Rieke, R.D. Highly reactive magnesium and its application to organic syntheses. J. Org. Chem. 1987, 16, 3674-3680. [CrossRef]

38. Forsberg, J.H.; Spaziano, V.T.; Klump, S.P. Lanthanide (III) ion catalyzed reaction of ammonia and nitriles: Synthesis of 2, 4, 6-trisubstituted-s-triazines. J. Heterocycl. Chem. 1988, 3, 767-770. [CrossRef]

39. Ronzio, A.R.; Cook, W.B. 4-amino-2, 6-dimethylpyrimidine. Organic Syntheses. CAS Number: 461-98-3, Product Number: A2091. Available online: http:/ / onlinelibrary.wiley.com/doi/10.1002/0471264180.os024. 03/abstract;jsessionid=7B439FE3BA33631CD8C7132C85FE0386.f02t03 (accessed on 31 January 2018).

40. Bossio, R.; Marcaccini, S.; Parrini, V. Synthesis of 5H-benzimidazo [1, 2-a] [1, 3, 4] thiadiazolo [2, 3-d] [1, 3, 5] triazin-5-one and $12 \mathrm{H}$-benzimidazo [1, 2-a] pyrimido [6, 1-d] [1, 3, 5] triazin-12-one, two new heterocyclic ring systems. J. Heterocycl. Chem. 1986, 3, 889-891. [CrossRef]

41. Zhang, W.M.; Zhang, L.; Liao, S.J. Cyclotrimerization of nitriles by the reactive alkali metal hydrides. Chin. Chem. Lett. 1995, 6, 839-842.

42. Zhang, W.; Liao, S.; Xu, Y. Application of alkali metal hydrides of nanometric size in reduction, cyclotrimerization and metalation. Synth. Commun. 1997, 22, 3977-3983.

43. Takaya, H.; Naota, T.; Murahashi, S. Iridium Hydride Complex Catalyzed Addition of Nitriles to Carbon-Nitrogen Triple Bonds of Nitriles. J. Am. Chem. Soc. 1998, 17, 4244-4245. [CrossRef]

44. Fengyun, L.; Weilin, S.; Zhou, D. Synthesis and characterization of a cyclic polyacetonitrile oligomer and its application on solid polymer electrolyte. Int. J. Electrochem. Sci. 2015, 10, 5561-5575.

45. Liu, X.; Xie, Y.; Liu, R.; Zhang, R.; Yan, H.; Yang, X.; Huang, Q.; He, W.; Yu, B.; Feng, Q.; et al. A cyclo-trimer of acetonitrile combining fluorescent property with ability to induce osteogenesis and its potential as multifunctional biomaterial. Acta Biomater. 2018, 65, 163-173. [CrossRef] [PubMed]

46. Dexu, H.; Cho, S.; Bang, M.; Bae, C.; Choi, Y.; Li, Y.; Lim, S.; Shim, J.; Park, D. FK-3000 isolated from Stephania delavayi Diels. inhibits MDA-MB-231 cell proliferation by decreasing NF-kB phosphorylation and COX-2 expression. Int. J. Oncol. 2015, 46, 2309-2316. [CrossRef] [PubMed]

47. Distefano, M.; Scambia, G.; Ferlini, C.; Gaggini, C.; De Vincenzo, R.; Riva, A.; Bombardelli, E.; Ojima, I.; Fattorossi, A.; Panici, P.B. Anti-proliferative activity of a new class of taxanes (14-hydroxy-10-deacetylbaccatin III derivatives) on multidrug-resistance-positive human cancer cells. Int. J. Cancer 1997, 72, 844-850. [CrossRef]

48. Zhang, X.; Dong, C.; Zapien, J.A.; Ismathullakhan, S.; Kang, Z.; Jie, J.; Zhang, X.; Chang, J.C.; Lee, C.; Lee, S. Polyhedral organic microcrystals: From cubes to rhombic dodecahedra. Angew. Chem. 2009, 48, 9121-9123. [CrossRef] [PubMed]

49. Liversidge, G.G.; Cundy, K.C.; Bishop, J.F. Surface Modified Drug Nanoparticles. U.S. Patent No. 5145684, 8 September 1992.

(C) 2018 by the authors. Licensee MDPI, Basel, Switzerland. This article is an open access article distributed under the terms and conditions of the Creative Commons Attribution (CC BY) license (http://creativecommons.org/licenses/by/4.0/). 